\title{
Relationships on the Job and Work-Related Stress within the Third Sector in Europe
}

\section{ABSTRACT}

The aim of the study is to analyse the association between occupational stress and interpersonal relationships on the job for non-profit workers in Europe. The main assumption of the paper is that social support coming from interpersonal relationships on the job may counteract stress caused by adverse working conditions. The econometric analysis, based on a standard ordered probit model, employs data from the Sixth European Working Conditions Survey carried out in 2015 and released in 2017. Four measures of relationships on the job were considered. Not only relationships on the job with the manager and with colleagues but also external contacts with clients and patients with whom employees interact with when performing their job are included in these relationships, and social interactions with family members made possible by the ability to conciliate working time with family or social commitments outside the job are included as well. The results show significant correlations between interpersonal contacts on the job and job-related stress. Workers who get along well with co-workers have a lower probability of reporting workrelated stress.

\section{KEY-WORDS}

WORK RELATED STRESS, NON-PROFIT SECTOR, RELATIONSHIPS ON THE JOB, ORDERED PROBIT MODEL, EUROPE 


\section{Introduction}

The third sector ${ }^{1}$ in Europe does not have a clear identity, and there is no consensus across Europe concerning the exact definition of the third sector and its role in the European public space (Enjolras et al., 2018). Indeed, very different kinds of organizations are included in this sector; however, these entities, though dissimilar, collectively constitute a coherent whole aimed at achieving social purposes rather than at generating profits. Contrary to for-profit firms, non-profit organizations have a non-distribution constraint that does not allow the distribution of residual earnings to board members. In the presence of asymmetric information, the non-distribution constraint is perceived as an indicator of credibility. The constraint demonstrates to uninformed consumers that the quality of the service cannot be prejudiced by the organization's aim of profit (Hansmann, 1980) and indicates to uninformed managers that they can perform their job without a risk of being disadvantaged by the organization's gain (Rose-Ackerman, 1996; Ben-Ner, Ren and Paulson, 2011).

Thus, the third sector employs people interested in a mixed structure that includes both extrinsic and intrinsic incentives and attracted by factors other than monetary compensation (Bacchiega and Borzaga, 2001; 2003; Borzaga and Musella, 2003). Indeed, non-profit organizations "are at their most effective when the people involved share common values and assumptions about the organization's purpose and its style of operation" (Hudson, 1999: 37).

The rapid transformations that have occurred within the labour market have also affected the non-profit sector: contemporary organizations, both for-profit and not-for-profit organizations, experience demanding challenges associated with changes in the organizational environment, which are increasingly characterized by rapid developments (Somaratne, Jayawardena and Perera, 2017). Therefore, non-profit workers, in addition to workers in other sectors, must face the pressure of work transformations, and occupational stress has become an issue affecting this sector as well.

The main aim of this paper is to study the association between relationships on the job and work-related stress in the European third sector. The reasons for studying the above association are at least four: 1) work-related stress is one of the most relevant social phenomenon and a question of public health (Vercamer, 2018); 2) the third sector is a sector where interpersonal contacts are important (Borzaga and Depedri, 2005; Borzaga and Musella, 2003); 3) the well-being of a person is also associated with the extent to which relationship needs are satisfied (Tan and Tay, 2018); 4) "stress occurs in a wide range of work circumstances but is often made worse when employees feel they have little support from supervisors and colleagues"2. The empirical analysis employs data from

Throughout the paper, the terms "non-profit" and "third sector" are used as synonyms.

World Health Organization. Stress at the workplace. Available at: http://www.who.int/occupational_health/topics/ stressatwp/en/ [Accessed: February 2020]. 
the Sixth European Working Conditions Survey (EWCS6) released in 2017 (EWCS, 2017). The survey presents a varied picture of Europeans at work over time and across countries, occupations, sexes and age groups. The paper focuses on the EU28 countries. The dependent variable used is job-related stress, as assessed by the prompt: "You experience stress in your work". It is a subjective measure of perceived work-related stress, which was collected through individual interviews. A standard ordered probit model is used to test the theoretical hypothesis concerning the association between interpersonal relationships and job-related stress. The original contribution of the paper to the literature is twofold. First, it adds a new piece of evidence to the literature on work-related stress, i.e., the correlation between interpersonal relationships on the job and occupational stress. Very few studies consider interpersonal on-the-job relationships as correlates of job stress (see Cummins, 1990; Baum, 1999; McKenzie et al., 2002; Russell et al., 2018). Second, it extends the evidence on the correlates of work-related stress with regard to a specific sector of the European labour market, i.e., the third sector.

The paper is organized into two main parts. To study the question from a theoretical viewpoint, the aim of the first part is to analyse the potential link between on-the-job relationships and workrelated stress, whereas the aim of the second part is to assess the correlation between on-the-job relationships and occupational stress.

\section{Work-related stress and interpersonal relationships within the third sector}

People spend most of their time working; therefore, their working environment is important for their well-being. Work-related stress arises "when the demands of the work environment exceed the workers' ability to cope with (or control) them" (EU-OSHA, 2009: 14). Work-related stress is likely to have negative consequences not only for employees in terms of poor health (Siegrist and i Rödel, 2006) but also for organizations since decreases in motivation (Um, Joo and Her, 2018) and occupational stress have a negative impact on workers' performance (French, Caplan and Harrison, 1982), absenteeism and turnover intention (Sager, 1994). For those reasons, job stress is a socioeconomic problem associated with high societal costs (Hassard et al., 2018).

The job demand-control-support model (Johnson and Hall, 1988; Karasek and Theorell, 1990) focuses on the relationship between work environment features and employee wellbeing. According to this model, it is possible to identify three significant features of the work environment: 1) job demands, 2) job control and 3) social support. A mixture of high job demands and low job control (high-strain jobs) and low social support (high iso-strain jobs) may have stressful outcomes: high job-related anxiety, low job satisfaction and isolation. Low-strain jobs, characterized by low job demands and high control, and low iso-strain jobs (low demands, high control and high social support) improve workers' well-being. Job demands are defined as the characteristics of work: the pace, the quantity and difficulty of work, and time-related pressure. Considering the characteristics of the job, the kind of job contract may be another 
factor of job stress when workers face job insecurity, which, in turn, can imply uncertainty in life and the inability to make plans for the future. In particular, the third sector, in Europe, is characterized by a large percentage of temporary contracts, which are mainly linked to temporary funding associated with specific projects (Enjolras et al., 2018). Since it is an aspect of the job demands, the number of working hours is driver of occupational stress as well: increases in working hours increases workload and tiredness and in turn increases stress. It is likely that employees in non-profit organizations work more hours than are designated by their contracts; however, this is true only for some groups of workers, and it does not seem to be the case for managers (Ariza-Montes and Lucia-Casademunt, 2016). However, some studies (see, for instance, Ridder and McCandless, 2010) show that since they are intrinsically motivated, non-profit employees have an extraordinary level of work commitment that push them to work overtime and be very absorbed in their jobs. Due to lack of time, frequently, employees who work a lot find difficult to conciliate work with family and this limitation, even if employees are intrinsically motivated, can be stressful. Indeed, the ability to conciliate work with family activities may become an important factor in reducing work-related stress (Karkoulian, Srour and Sinan, 2016; Li, Wu and Johson, 2016); this is particularly true for women (whose percentage in the third sector is high) who generally have to care for their children and who are likely to perform most of the house/family responsibilities (Makhija, Naidu and Rakesh, 2016; Mittal and Bhakar, 2018). Finding a suitable balance between work and family is not easy; when it becomes difficult to equipoise work with family commitments, this mismatch can become a source of stress (ILO, 2012; 2016) and this is likely to happen to non-profit workers.

Job control or job latitude is the possibility of "having control over tasks and conduct during the working day" (Karasek, 1979: 289). Job control may reduce workers' perceptions of undue job demands. Social support is "helpful social interaction available from co-workers and/or supervisors in terms of task assistance for coping with work-related problems" (Karasek and Theorell, 1990: 19). Supervisor support and job control can be considered a job resource, which can be useful for addressing job demands (Bakker and Demerouti, 2007). The supervisor's support can influence job demands since the supervisor can help workers perform their tasks and provide advice and opinions on their performance. In addition, supervisors assign tasks to employees. Therefore, good relationships with supervisors can decrease the workload and overall pressure (Hobfoll, 2001).

Social support should be present particularly within non-profit firms, which seem to be more inclined than for-profit enterprises to create a work environment where the overall quality of interpersonal relationships among colleagues, between managers and workers, and between workers and clients are valued (Borzaga and Depedri, 2005).

According to the literature (see, among others, Ariza-Montes and Lucia-Casademunt, 2016; Enjolras et al., 2018), it seems that third sector employees more commonly face poor, unfavourable and precarious working conditions, low wages, and job instability compared to for-profit sector employees. For this reason, looking at the sociodemographic characteristics of 
third sector workers, there are more women than there are men (also because they are likely more pro socially oriented), and there are more young workers than there are old workers: both women and young workers, to whom accessing to the labour market is more difficult, are more prepared to meet the needs of the sector. However, the third sector attracts employees and creates employment opportunities for people who share ideological motivations, feel empathy with certain principles, and are not exclusively motivated by extrinsic motivations such as monetary remuneration. This sector provides intrinsic incentives that meet intrinsic motivations. Many studies (Souza-Posa and Souza-Posa, 2000; Helliwell and Huang, 2010) have shown that remuneration is not one of the most important drivers of job satisfaction. Compensation is preceded by other determinants, such as the possibility of performing autonomous tasks, good relationships with the job, job stability and involvement in firm decisions (Clark, 2005). Furthermore, according to Pugno and Depedri (2010), interest in the job accounts more for job satisfaction than economic incentives. Thus, nonpecuniary compensation is likely to balance extrinsic factors, and this is particularly applicable in the third sector, where employees share the firms' missions and do not work just for money. Indeed, it is interesting to observe that although non-profit workers are likely to face not very favourable working conditions, previous research studies have generally confirmed that worker satisfaction in non-profits is high, and this is likely to occur since workers in the third sector are intrinsically motivated: "intrinsic other-regarding and relational attitudes are those that best support greater satisfaction" (Borzaga and Tortia, 2006: 241).

Intrinsic factors such as positive relationships on the job with co-workers and with the manager and the possibility of balancing the working time with familiar and social commitments contrast extrinsic factors (low wages, working hours, the typology of contract) and poor working conditions, which are drivers of work-related stress (Cohen and Willis, 1985; Nappo, 2019). According to the demand-control-support model, emotional support and help in performing the job derived from positive interpersonal contacts on the job are likely to buffer the negative effects of high demands and a low level of control. Encouraging relationships with colleagues and superiors may lessen (buffer) stressful situations (Baum, 1999; McKenzie, Whitley and Weich, 2002). Cummins (1990) reached the conclusion that workers who maintain good relations with their supervisors and co-workers are usually efficacious and productive at work, even when workrelated stress is high. Several studies (see, among others, Russell et al., 2018) have indicated that social support can be a helpful resource for workers and have shown that support from co-workers and managers is a significant factor in controlling the consequence of high emotional demands. These findings imply that workers exposed to high emotional demands are likely more able to cope with them when they have appropriate help from their colleagues. Given their position, supervisors can monitor employees' problems and help them search for resources to neutralize their stress (Boz, Martinez-Corts and Munduate, 2009). Co-workers can support colleagues to accomplish work-related tasks, decreasing stress levels (Gouldner, 1960), especially in the third 
sector, which is a sector characterized mostly by labour-intensive processes (Enjolras et al., 2018). Other studies (Kahn et al., 1964; Kahn, 1980) have clarified that interpersonal contacts (and personality features) can lessen the impact of several factors, such as role ambiguity, role conflict, overload (quantitative and qualitative), withdrawal, low self-confidence, low job satisfaction and job tension, on stress intensity.

For the above arguments, to study the association between relationships on the job and workrelated stress in the third sector, this paper considers four indicators of relationships on the job: 1) if the boss is successful in getting people to work together; 2) if there is good cooperation between workers and their colleagues; 3) if generally workers get on well with their colleagues; 4) if workers are helped and supported by colleagues (see Section 5 for differences between indicator 2 and 4). In addition, considering works that involve visiting customers, patients, clients or working at their premises or in their home allows understanding if external interpersonal contacts (arising from work) are correlates of work related stress as well.

The following empirical hypothesis is set up:

$H$ : workers who have good relationships on the job experience less work-related stress than workers who do not have good relationships on the job.

\section{Data}

The econometric analysis employs data from the Sixth European Working Conditions Survey carried out in 2015 and released in 2017. The data were accessed and downloaded via the UK Data Service. The survey provides a wide assessment of Europeans at work over time across countries, occupations, sexes and age groups. Since its launch in 1990, the European Working Conditions Survey has provided an overview of working conditions in Europe. A random sample of workers are interviewed face-to-face. Overall, to date, approximately 43,000 employees aged 15 and over have been interviewed. The survey includes topics related to employment status, working time duration and organization, work organization, learning and training, physical and psychosocial risk factors, health and safety, work-life balance, worker participation, earnings and financial security, and work and health. The sample includes individuals from 35 countries, including the EU28, Norway, Switzerland, Albania, North Macedonia, Montenegro, Serbia and Turkey. No panel dimension is available.

The survey includes information on employees working within ${ }^{3} 1$ ) the private sector, 2) the public sector, 3) joint private-public organizations or companies, 4) the not-for-profit sector or an NGO and 5) other types of workplaces. The study focuses only on the not-for-profit sector or NGO workers, workers of all other sectors are excluded.

3 Question n. 14 of the EWCS6 Questionnaire: "Are you working in...?” 
The econometric analysis focuses on the following EU28 ${ }^{4}$ countries for which information on non-profit workers are available (the number of observations per country are in parentheses): Austria (11), Belgium (30), Bulgaria (4), Croatia (8), Cyprus (9), Czech Republic (5), Denmark (5), Estonia (8), Finland (8), France (24), Germany (64), Hungary (10), Ireland (8), Italy (4), Latvia (6), Lithuania (1), Luxembourg (3), Malta (5), the Netherlands (12), Poland (2), Portugal (7), Slovakia (4), Slovenia (6), Spain (2), Sweden (4), and the United Kingdom (18).

The respondents who did not meet the selection criteria or had missing data on dependent and independent variables were excluded, so that the final dataset comprised a cross-sectional sample of 182 observations. Such a narrow sample, although provides statistically significant information on the association between relationships on the job and work-related stress within the third sector in Europe, does not allow for a generalization of the results, since a small sample has a higher likelihood of not accurately representing the population (Cochran, 1977; Duin, 1995).

\subsection{Dependent Variable}

The dependent variable "job-related stress" is assessed with the following question: "You experience stress in your work"s. Job-related stress is a subjective indicator of perceived occupational stress and has been measured by individual interviews. Responses are expressed on a scale from 1 ("always") to 5 ("never"). The data show that $6.2 \%$ of the sample "always" experiences stress, $15.42 \%$ experience it "most of the time", $44.74 \%$ experience it "sometimes", $17.29 \%$ experience it "rarely", and $16.54 \%$ "never" experience it.

\subsection{Independent Variables}

The selection of the appropriate explanatory variables was motivated by theory; in particular, we referred to the "demand-control-support" model and to the distinction between extrinsic and intrinsic factors that motivate employees to choose the sector (for profit, non-profit) within which they work differently. Four measures of relationships on the job were considered. A number of standard socioeconomic control variables are included in the econometric analysis as well. Tables 1 and 1a provide a description of the independent variables used in the empirical model and descriptive statistics for the sample, respectively.

\footnotetext{
4 At the time of writing, Brexit was not yet effective.

5 Question n. 61m of the EWCS6 Questionnaire.
} 
Table 1. Definition of the independent variables

Variable Description

\begin{tabular}{|c|c|}
\hline Male & 1 if male; 0 otherwise \\
\hline Age & 1 if she/he is $17 / 40$ years old at the time of the survey interview, 0 otherwise \\
\hline Has a spouse or a partner & 1 if she/he has a spouse or a partner, 0 otherwise \\
\hline Has a child & 1 if she/he has at least one child and 0 otherwise \\
\hline Low level of education & $\begin{array}{l}1 \text { if highest level of education is primary education, } 0 \text { otherwise } \\
\text { (reference group) }\end{array}$ \\
\hline Middle level of education & 1 if highest level of education is secondary education, 0 otherwise \\
\hline High level of education & 1 if highest level of education is tertiary education, 0 otherwise \\
\hline Ends meet & $\begin{array}{l}\text { How the interviewee household total monthly income is able to make ends meet (from } 1 \text { "very easily" to } \\
6 \text { "with great difficulty") }{ }^{6}\end{array}$ \\
\hline Health & How the interviewer health is in general (from 1 "very good" to 5 "very bad") \\
\hline
\end{tabular}

\section{Extrinsic features}

Permanent job $\quad 1$ if the employment contract has an unlimited duration, 0 otherwise

Part time job $\quad 1$ if she/he works part time, 0 otherwise

Up to twenty hours $\quad 1$ if the interviewee usually works up to 20 hours per week, 0 otherwise

\section{Job characteristics}

\begin{tabular}{ll}
\hline Work affects health1 & 1 if her/his work affects health mainly positively, 0 otherwise \\
\hline Work affects health2 & 1 if her/his work affects health mainly negatively, 0 otherwise \\
\hline Work affects health3 & 1 if her/his work does not affect health, 0 otherwise (reference group) \\
\hline Job involvement & 1 if the worker is consulted before objectives are set for her/his work, 0 otherwise \\
\hline External Contacts & $\begin{array}{l}1 \text { if her/his work involves visiting customers, patients, clients or working at their premises or in their home, } \\
0 \text { otherwise }\end{array}$ \\
\hline Work and Family & \begin{tabular}{l}
1 if her/his working hours fits in with her/his family or social commitments outside work, 0 otherwise \\
\hline Job satisfaction
\end{tabular} \\
\hline
\end{tabular}

\section{Relationships on the job}

Boss relations If her/his boss is successful in getting people to work together (from 1 "strongly agree" to 5 "strongly disagree")

Colleagues Cooperation If there is good cooperation between she/he and her/his colleagues (from 1 "strongly agree" to 5 "strongly disagree")

Get on well Colleagues If generally she/he gets on well with her/his work colleagues (from 1 "strongly agree" to 5 "strongly disagree")

Colleagues Support $\quad 1$ if her/his colleagues help and support her/him (from 1 "always" to 5 "never")

6 Employers' wage is an important theoretical variable for this paper. However, due to the high number of missing values on the monthly earning variable, the "ends meet" variable has been used as a proxy of individual wage (even though "ends meet" is not an individual measure but it refers to the interviewee household). 
Table 1a. Descriptive statistics of the independent variables

\begin{tabular}{|c|c|c|c|c|}
\hline Variable & Mean & Std. Dev. & Min & $\operatorname{Max}$ \\
\hline \multicolumn{5}{|l|}{ Demographic } \\
\hline Male & .3171642 & .4662426 & 0 & 1 \\
\hline Age & .3880597 & .48822 & 0 & 1 \\
\hline Has a spouse or a partner & .5597015 & .4973517 & 0 & 1 \\
\hline Has a child & .3432836 & .4756935 & 0 & 1 \\
\hline Low level of education & .1791045 & .3841572 & 0 & 1 \\
\hline Middle level of education & .6604478 & .4744433 & 0 & 1 \\
\hline High level of education & .1604478 & .3677075 & 0 & 1 \\
\hline Ends meet & 3.123596 & 1.313495 & 0 & 6 \\
\hline Health & 2.033582 & .8272009 & 1 & 4 \\
\hline
\end{tabular}

Extrinsic features

\begin{tabular}{lllll}
\hline Permanent job & .6977612 & .4600873 & 0 & 1 \\
\hline Part time job & .4148472 & .4937749 & 0 & 1 \\
\hline Up to twenty hours & .3018868 & .4599451 & 0 & 1 \\
\hline
\end{tabular}

Job characteristics

\begin{tabular}{lllll}
\hline Work affects health1 & .1969112 & .3984346 & 0 & 1 \\
\hline Work affects health2 & .2046332 & .4042144 & 0 & 1 \\
\hline Work affects health3 & .5984556 & .4911598 & 0 & 1 \\
\hline Job involvement & .3100775 & .4634241 & 0 & 1 \\
\hline External Contacts & .358209 & .480371 & 0 \\
\hline Work and Family & .5037594 & .5009283 & 0 \\
\hline Job satisfaction & .8598485 & .3478035 & 0 & 1 \\
\hline
\end{tabular}

Relationships on the job

\begin{tabular}{lcccc}
\hline Boss relations & 2.105058 & 1.208957 & 1 & 5 \\
\hline Colleagues Cooperation & 1.566406 & .7537386 & 1 & 5 \\
\hline Get on well Colleagues & 1.529183 & .7706306 & 1 & 5 \\
\hline Colleagues Support & 1.76209 & .9753308 & 5 \\
\hline
\end{tabular}

\subsection{Methodology}

The theoretical hypothesis concerning the association between work-related stress and interpersonal relationships on the job is tested using a standard ordered probit model that is generally used to study discrete data of this kind. The model is built around a latent regression of the following form: 


$$
y_{i}^{*}=x_{i}^{\prime} \beta+\varepsilon_{i}
$$

where $x$ and $\beta$ are the matrix of control variables and the vector of unknown parameters, respectively, $\varepsilon$ is the error term, the subscript $i$ denotes an individual observation, and, as usual, $y^{*}$ is the unobserved result. We observe the following:

$$
\begin{aligned}
& \mathrm{y}=0 \text { if } y^{*} \leq 0 \\
& \mathrm{y}=1 \text { if } 0<y^{*} \leq \mu_{1} \\
& \mathrm{y}=\mathrm{J} \text { if } \mu_{J-1} \leq y^{*}
\end{aligned}
$$

indicating a form of censoring. Furthermore, $\mu^{\prime}$ is an unknown parameter to be estimated with $\beta$. We do not observe $y^{*}$ in the data. Rather, we observe the dependent variable, work-related stress.

\section{Results}

With the ordered probit model, the interpretation of the coefficients is not easy (Daykin and Moffatt, 2002), and neither the sign nor the magnitude of a coefficient provides information on the partial effects of a given explanatory variable. Therefore, we estimate the marginal effects, which allow us to interpret the effect of the regressors on the dependent variable. Marginal effects provide a measure of the expected direct change in the dependent variable as a function of the change in a certain explanatory variable while all other covariates are held constant. The marginal effects of the regressors, expressed in terms of a change in the independent variables on the probability of "always" experiencing work-related stress and on the probability of "never" experiencing work-related stress, give information on the magnitude of the correlations between work-related stress and relationships on the job.

Table 2 shows the ordered probit estimates (column 1) and marginal effects $(d x / d y)$ of a change in the regressors on the probability of "always" (outcome 1, column 4) and "never" (outcome 5, column 7) experiencing work-related stress. It is necessary to explain that the results of the econometric investigation, as part of a cross-sectional study (the data do not have a panel dimension), identify correlations rather than cause-and-effect relations between workrelated stress and relationships on the job, and an association does not define causation. We cannot identify a clear causal relationship in one direction or another between two variables: causation may apply to both directions, as employees who do not experience work-related stress have more opportunities to interact on the job and interpersonal contacts on the job influence employees' work-related stress. 
Table 2. Correlates of work related stress

Always Never

\begin{tabular}{|c|c|c|c|c|c|c|c|c|c|}
\hline Variable & Coeff & $S E$ & $P>|z|$ & $d x / d y$ & $S E$ & $P>|z|$ & $d x / d y$ & $S E$ & $P>|z|$ \\
\hline \multicolumn{10}{|l|}{ Demographic } \\
\hline Male & -.1782827 & .224357 & 0.427 & $.0133928^{*}$ & .01914 & 0.070 & -.0251405 & .02993 & 0.401 \\
\hline Age & $.3492123^{*}$ & .1896204 & 0.066 & .0269681 & .01928 & 0.162 & $-.0487049^{*}$ & .02659 & 0.067 \\
\hline Has a spouse or a partner & -.0244205 & .2005656 & 0.903 & .0017141 & .01401 & 0.903 & -.0036153 & .02987 & 0.904 \\
\hline Has a child & .2287674 & .1861956 & 0.219 & -.0154382 & .01306 & 0.237 & .0350859 & .03014 & 0.244 \\
\hline $\begin{array}{l}\text { Middle level of } \\
\text { education }\end{array}$ & $-.4897776^{*}$ & .2857945 & 0.087 & $.0303054^{*}$ & .01761 & 0.085 & -.0815529 & .05472 & 0.136 \\
\hline High level of education & -.2635469 & .3436071 & 0.443 & .0218068 & .03306 & 0.509 & -.0345105 & .04004 & 0.389 \\
\hline Ends meet & .0074118 & .067759 & 0.913 & -.000523 & .00476 & 0.913 & .0010928 & .01001 & 0.913 \\
\hline Health & .0669389 & .1217446 & 0.582 & -.0047234 & .00872 & 0.588 & .0098697 & .01772 & 0.578 \\
\hline
\end{tabular}

\begin{tabular}{|c|c|c|c|c|c|c|c|c|c|}
\hline Permanent job & $-.4977245^{* *}$ & .223783 & 0.026 & $.0283341^{*}$ & .01473 & 0.054 & $-.0876631^{*}$ & .04548 & 0.054 \\
\hline Part time job & .1220577 & .1866508 & 0.513 & -.0084093 & .01299 & 0.517 & .0183553 & .0286 & 0.521 \\
\hline Up to twenty hours & -.0690788 & .2290604 & 0.763 & .0050627 & .0176 & 0.774 & -.009899 & .03161 & 0.754 \\
\hline \multicolumn{10}{|l|}{ Job characteristics } \\
\hline Work affects health 1 & -.0638657 & .2281703 & 0.780 & .004673 & .01776 & 0.792 & -.0091627 & .03219 & 0.776 \\
\hline Work affects health2 & $-.5664269^{* *}$ & .2398843 & 0.018 & $.0539087^{*}$ & .03174 & 0.089 & $-.0677149^{* * *}$ & .02587 & 0.009 \\
\hline Job involvement & -.0014274 & .2022158 & 0.994 & .0001008 & .01429 & 0.994 & -.0002104 & .02979 & 0.994 \\
\hline Work and Family & $.5640613^{* * *}$ & .1684581 & 0.001 & $-.040203^{* *}$ & .01745 & 0.021 & $.0856328^{* * *}$ & .03109 & 0.006 \\
\hline Job satisfaction & $.6134082^{* *}$ & .260145 & 0.018 & -.0651477 & .04215 & 0.122 & $.0665256^{* * *}$ & .02336 & 0.004 \\
\hline \multicolumn{10}{|l|}{ Relationships on the job } \\
\hline Boss relations & $-.1909543^{* * *}$ & .069809 & 0.006 & $-.0134744^{* *}$ & .00614 & 0.028 & $.028155^{* *}$ & .01141 & 0.014 \\
\hline Colleagues Cooperation & $.3355022^{* *}$ & .1482781 & 0.024 & $-.0236742^{*}$ & .01218 & 0.052 & $.0494677^{* *}$ & .0232 & 0.033 \\
\hline Get on well Colleagues & -.2071669 & .136942 & 0.130 & .0146184 & .01028 & 0.155 & -.0305454 & .02108 & 0.147 \\
\hline Colleagues Support & -.1343027 & .1162578 & 0.248 & .0094768 & .00842 & 0.260 & -.0198021 & .0169 & 0.241 \\
\hline
\end{tabular}

${ }^{* * *}$ stat. signif. at $1 \%$; ${ }^{* *}$ stat. signif. at $5 \%{ }^{*}$ stat. signif. at $10 \%$. 
The results reported in column 1 provide information on the statistical significance of the correlation between the explanatory variables and work-related stress, and the variables of interest show that both the supervisor's ability to get people to work together and favourable cooperation between colleagues are significantly correlated with job-related stress. Regarding the marginal effects (columns 4 and 7), the results show that males have a $1.33 \%$ higher probabilities of reporting that they always experience stress than females. This result is not in line with the literature (see, for instance, Russell et al., 2018), for which females are likely to report higher work-related stress levels: probably this is not the case for the third sector where female sometimes chose to work for several reasons (i.e. their propensity to take care of others, the importance of relationships within the sector, the possibility of working part-time). Workers aged $17-40$ have a $4.87 \%$ lower probability of reporting that they never experience stress than older workers. This result may be explained by the idea that young workers may have greater difficulty in dealing with workday life when it involves performing activities that are mostly labour intensive and that require a learning by doing process that improves over time. Workers with a middle level of education have a 3.03\% higher probability of reporting that they always experience work-related stress than workers who have a low level of education. One of the explanations for this result is that workers with higher levels of education have more working responsibilities and carry out more demanding jobs than workers with low levels of education do (see, among others, Lunau et al., 2015).

Workers who are employed with contracts of unlimited duration have a $2.83 \%$ higher and an $8.76 \%$ lower probability of always and never experiencing work-related stress, respectively, than temporary workers. This result is in line with a strand of the literature (see, for instance, Eiken and Saksvik, 2009; Inoue, Tsurugano and Yano et al., 2011) and can be explained by considering that permanent workers feel charged with more responsibility than temporary workers, who face lower levels of job demands. Workers whose job affects mainly negatively their health have a $5.39 \%$ higher and a $6.77 \%$ lower probability of reporting that they always and never experience stress. Workers whose job involves visiting customers, patients, or clients at their homes have a $3.19 \%$ higher and a $5.85 \%$ lower probability of reporting that they always and never experience stress, respectively, than workers who do not visit clients. Employees who are satisfied with their working conditions have a $6.65 \%$ higher probability of reporting that they never experience work-related stress than workers who are not satisfied. Workers who are able to conciliate working time with family or social commitments show a $4.02 \%$ lower and an $8.56 \%$ higher probability of always and never experiencing work-related stress, respectively, than workers who are not able to do this. Workers who have a supervisor that is successful in getting people to work together have a $1.34 \%$ lower and a $2.81 \%$ higher probability of reporting that they always and never experience work-related stress. Increasing the cooperation between colleagues decreases the probability of them reporting work-related stress and increases the probability of them reporting that they never experience stress. 


\section{Discussion}

There are two main characteristics of the non-profit sector: 1) non-profit workers are very much pro-socially motivated in their job, and 2) deteriorating working conditions that make working in the third sector quite unattractive manifest in mental and physical stress in employees (Enjolras et al., 2018). As stated in section 2, according to the demand-control-support model (Karasek and Theorell, 1990), unfavourable effects of adverse working conditions are likely to be counteracted by social support derived from good relationships on the job. In line with our expectations, our results show that overall, within the non-profit sector, interpersonal relationships are important for work-related stress. Not only relationships on the job with the manager and with colleagues but also external contacts with clients and patients with whom employees interact with when performing their job are included in these relationships, and social interactions with family members made possible by the ability to conciliate working time with family or social commitments outside the job are included as well.

In the following section, we discuss predictive drivers of job-related stress for employees in nonprofit organizations focusing on interpersonal contacts (social support).

Enjoying the benefits of a supportive working environment where interpersonal relations are genuine makes the difference with regard to occupational stress: social support is a strong remedy against job stressors (Mayo et al., 2012). This seems to be particularly true with respect to nonprofit organizations where good on-the-job relations, from which support comes, are considered an important part of the mix of relational incentives offered to induce workers to do their best (Borzaga and Depedri, 2005). Social support is a moderator of life stress (Cobb, 1976). According to Thoits (2010: S46), social support can be generally defined as "emotional, informational, or practical assistance from significant others, such as family members, friends, or co-workers; (and that) support actually may be received from others or simply perceived to be available when needed". Support on the job can come both from managers and from co-workers. Managers and co-workers play different roles within the organization and can therefore provide different social support through different channels. Both the former and the latter can sustain employees' complaints and provide the employees with proper physical and psychological help to overcome difficulties and to perform tasks. In addition, both managers and co-workers can be sources of stress and resources to alleviate stress. Regarding managers, they are likely to decide employees' main responsibilities; for this reason, workers can identify their supervisor as the main source of job demands. Therefore, even if the manager is friendly, the relationship with her/him can be perceived as stressful. To alleviate workers' stress, managers should always consider the factors that are under their responsibility: employees' knowledge of what to expect in their daily routine; clarity in communication; supervisor support; management support in favour of employees and encouragement to be supportive of each other (Pomerantz, 1991).

Regarding colleagues, interpersonal relationships among them can be perceived as frustrating because of competition that may arise among peers. However, this should not occur in non-profit organizations, where workers aim to fulfil a common and shared objective, which is their organization's 
mission (Hudson, 1999). We considered three measures of interpersonal contacts with colleagues that are supposed to provide social support to buffer job stress: a) this has been possible since the EWCS (2017) provides plenty of information on relationships and b) it could be considered a strength of the paper since most studies include a lower number of interpersonal contacts indicators (see, among others, Russell et al., 2018). The interpersonal contacts explanatory variables are: 1) good cooperation with colleagues; 2) getting on well with colleagues; and 3) colleagues' help and support. Those three measures are different among them. Cooperation implies "working together with somebody else to achieve something" (Wehmeier, 1998: 141): the pursuit of the common goal excludes that there may be competition among colleagues, which is likely stressing (Leiter and Maslach, 1988). Getting on well means "to have a good relationship" (Wehmeier, 1998: 268). In the Survey ${ }^{7}$, help and support coming from co-workers imply material aid that could be regardless of good relationships among colleagues therefore could not buffer stress. In addition, help and support from co-workers could also cause competition among peers and therefore it could produce job stress (Leiter and Maslach, 1988). Results show that the "help and support from co-workers" variable is not significant. This result is not in line with Russell et al. (2018) who employ the same data (EWCS 2017) but focus only on Irish employees (working within the private sector, the public sector, joint private-public organisation or company, the not-for-profit sector or an NGO, and other). Contrary to our expectations, also the "getting on well with colleagues" variable is not significant. Therefore, regarding relationships on the job with colleagues, our results confirm in part our expectations and show that only cooperation with colleagues decreases the probability of experiencing stress, this supports the positive and gratifying aspects of contacts with co-workers that have been reported in the literature (see, among others, Beehr, 1985; McKenzie, Whitley and Weich, 2002). Furthermore, the success of the supervisor in getting people to work together has a positive impact on employees who report a low level of work-related stress.

The kind of work performed in the third sector implies that the most important activity occurs outside of formal organizations. Workers may have to visit customers, patients, or clients at home to complete their job-related tasks. Interaction with customers, patients, or clients could provide social support as well. However, results show that employees whose job involves reaching clients have a higher probability of experiencing stress, therefore, relationships with customers, patients, or clients do not alleviate stress: this is likely to happen since working outside the organization and reaching people at their venue can be demanding, especially when people travel from one place to another frequently and within areas where accessibility is low (because of a lack of public transport or intense traffic). In addition, such jobs are likely to include performing jobs for persons with problems (i.e., alcoholics, elderly people). For the above reasons, workers who perform work outside the organization may feel overloaded and more stressed than their colleagues who do not work outside the organization.

Question n. 61 in the Questionnaire. 
A large body of the literature (see, among others, Leiter and Maslach, 1988; Babin and Boles, 1996; Russell et al. 2018) shows that being helped and supported by the manager decreases the probability of being stressed at work. Indeed, "managers have a leading role to play in determining the social climate at work" (Eurofound 2017: 66). Our result on the explanatory variable "boss relations" seems to be in line with the above literature and shows that the boss is likely to play a key role for workers wellbeing. Furthermore, such result might contribute to add a new piece of evidence to the existing literature with regard to a specific sector of the labour market: the European third sector.

\section{Conclusions}

The European "third or social economy (TSE) sector" accounts for slightly more than 13\% (employed individuals and volunteers) of the European workforce (Enjolras et al., 2018), with cooperatives and social enterprises contributing in a significant way to labour market integration. The recent rapid global labour market advancements have also been affecting the third sector organizations, which should begin processing new actions to encounter the challenges they face. In this scenario, work-related stress has become a serious problem that both employees and nonprofit organizations have to face since occupational stress can have unbearable effects, including low performance, turnover intention, and absenteeism. Therefore, proper and targeted actions to avoid and to address occupational stress are needed. Indeed, work related stress is often considered a private/personal problem with which employees have to cope with personal resources. On the contrary, firms should help workers to cope with job stress providing any kind of support needed (reducing job demand, increasing job control, providing good work conditions, helping employees to cooperate among them and with manager) and psychological assistance as well.

In this paper, we analysed the correlation between interpersonal relationships on the job and work-related stress using data from the sixth EWCS (2017). We built upon the assumption of the demand-control-support model that social support is a good resource to face job demands. Although the paper has not been able to determine the cause-effect relationship between relationships on the job and work-related stress (no panel dimension is available), the results show that social support derived from relationships on the job with managers and with colleagues is a good moderator of occupational stress. However, we considered several indicators of interpersonal relationships that could provide social support on the job and not all confirm our expectations. Particularly as regards interactions with colleagues, only social support coming from cooperation with co-workers is positively correlated with work related stress. This is likely to happen since cooperation implies working together to achieve an aim and it is not likely to involve competition as it could happen when employees help colleagues in a performance. It is interesting that external contacts with customers, patients, or clients, which produce interpersonal relationships as well, do not buffer stress, probably also for the reason that such works are likely to include performing jobs for persons 
with problems (i.e., alcoholics, elderly people). Although results help to understand which kinds of interpersonal relationships may provide social support for alleviating job-related stress, a limitation of the paper is the small sample that does not allow for a generalization of the results. Indeed, the sample size implies that results need further confirmation by future more robust statistical analyses. However, for further investigations, data are needed: a hope is that the next EWCS would enlarge the third sector sample. Thus, it could be possible trying to confirm the results also with country based analyses, which could be a fruitful avenue for research.

Though the above limitation, results seem interesting in terms of policy suggestions: 1) the nonprofit sector should select managers who have a good propensity to make employees work in team, since cooperation among co-workers is likely to buffer job stress; 2) managers should promote the sharing of goals in the implementation of the work (cooperation) among colleagues.

\section{References}

Ariza-Montes, A. \& Lucia-Casademunt, A.M. (2016). Nonprofit versus For-Profit Organizations: A European Overview of Employees' Work Conditions, Human Service Organizations: Management, Leadership \& Governance, 40(4): 334-351. DOI: https://doi.org/10.1080/23303131.2015.1134742

Babin, J.B. \& Boles, J.S. (1996). The Effects of Perceived Co-Worker Involvement and Supervisor Support on Service Provider Role Stress, Performance and job Satisfaction, Journal of Retailing, 72(1): 57-75. DOI: https://doi. org/10.1016/S0022-4359(96)90005-6

Bacchiega, A. \& Borzaga, C. (2001). Social enterprise as an incentive structure. In: C. Borzaga \& J. Defourny (Eds.), The Emergence of Social Enterprise. London: Routledge, pp. 273-295.

Bacchiega, A. \& Borzaga, C. (2003). The economics of the third sector: toward a more comprehensive approach. In: H.K. Anheier \& A. Ben-Ner (Eds.), The Study of the Nonprofit Enterprise: theories and approaches. New York: Kluwer Academic/Plenum Publishers, pp. 27-48. DOI: https://doi.org/10.1007/978-1-4615-0131-2_2

Bakker, A.B. \& Demerouti, E. (2007). The job demands-resources model: State of the art, Journal of managerial psychology, 22(3): 309-328. DOI: https://doi.org/10.1108/02683940710733115

Baum, F. (1999). Social capital: Is it good for your health? Issues for a public health agenda, Journal of Epidemiology and Community Health, 53(4): 195-196. DOI: http://dx.doi.org/10.1136/jech.53.4.195

Beehr, T.A. (1985). The role of social support in coping with organizational stress. In: T.A. Beehr \& R.S. Bhagat (Eds.), Human stress and cognition in organizations. New York: Wiley, pp. 375-398.

Ben-Ner, A., Ren, T. \& Paulson, D.F. (2011). A Sectoral Comparison of Wage Levels and Wage Inequality in Human Services Industries, Nonprofit and Voluntary Sector Quarterly, 40(4): 608-633. DOI: https://doi. org/10.1177/0899764010365012

Borzaga, C. \& Depedri, S. (2005). Interpersonal relations and job satisfaction: Some empirical results in social and community care services. In: B. Gui \& R. Sugden (Eds.), Economics and social interaction: Accounting for interpersonal relation. Cambridge: Cambridge University Press, pp. 132-153. DOI: https://doi.org/10.1017/ cbo9780511522154.007

Borzaga, C. \& Musella, M. (2003). Produttività ed efficienza nelle organizzazioni non profit, il ruolo dei lavoratori e delle relazioni di lavoro [Productivity and efficiency in non-profit organizations, the role of workers and labor relations]. Trento: Edizioni 31.

Borzaga, C. \& Tortia, E. (2006). Worker motivations, job satisfaction, and loyalty in public and nonprofit social services, Nonprofit and Voluntary Sector Quarterly, 35(2): 225-248. DOI: https://doi.org/10.1177/0899764006287207 
Boz, M., Martínez-Corts, I. \& Munduate, L. (2009). Breaking negative consequences of relationship conflicts at work: The moderating role of work family enrichment and supervisor support, Revista de Psicología del Trabajo y de las Organizaciones, 25(2): 113-121. DOI: https://doi.org/10.4321/s1576-59622009000200002

Clark, A. (2005) What Makes a Good Job? Evidence from OECD Countries. In: Bazen S., Lucifora C. \& Salverda W. (Eds.), Job quality and Employer Behaviour. London: Palgrave McMillan, pp. 11-30. DOI: https://doi. org/10.1057/9780230378643_2

Cobb, S. (1976). Social support as a moderator of life stress, Psychosomatic Medicine, 38(5): 300-314. DOI: https://doi. org/10.1097/00006842-197609000-00003

Cohen S. \& Wills T.A. (1985). Stress, social support, and the buffering hypothesis, Psychological Bulletin, 98: 310-357. DOI: https://doi.org/10.1037/0033-2909.98.2.310

Cochran, W.G. (1977). Sampling Techniques. 3rd ed. John Wiley \& Sons.

Cummins, R.C. (1990). Job stress and the buffering effect of supervisory support, Group and Organization Studies, 15(1): 92-104. DOI: https://doi.org/10.1177/105960119001500107

Daykin, A.R. \& Moffatt, P.G. (2002). Analysing ordered responses: A review of the ordered probit model, Understanding Statistics: Statistical Issues in Psychology, Education, and the Social Sciences, 1(3): 157-166. DOI: https://doi. org/10.1207/s15328031us0103_02

Duin, R.P.W. (1995). Small sample size generalization. In: Borgefors, G. (Ed.), Proceedings of the 9th Scandinavian Conference on Image Analysis, Vol. 2: 957-964.

Eiken, T.E. \& Saksvik, P.Ø. (2009). Temporary employment as a risk factor for occupational stress and health, Policy and Practise in Health and Safety, 7(2):75-91. DOI: https://doi.org/10.1080/14774003.2009.11667735

Eurofound (2017). Sixth European Working Conditions Survey - Overview report (2017 update). Luxembourg: Publications Office of the European Union.

EU-OSHA. (2009). European agency for safety and health at work, OSH in figures: Stress at work-facts and figures, European communities. Luxembourg. Available at: https://osha.europa.eu/en/publications/osh-figures-stresswork-facts-and-figures/view [Accessed: February 2020]

EWCS - European Foundation for the Improvement of Living and Working Conditions (2017). European Working Conditions Survey, 2015 [data collection]. 6th Edition. UK Data Service. DOI: http://doi.org/10.5255/UKDASN-8098-4

Enjolras, B., Salamon, L.M., Sivesind, K.H. \& Zimmer A. (2018). The Third Sector as Renewable Resource for Europe: Concepts, Impacts, Challenges and Opportunities. Cham: Palgrave Macmillan. DOI: https://doi.org/10.1007/9783-319-71473-8

French, J.R.P., Caplan, R.D. \& Harrison, R.V. (1982). The mechanisms of job stress and strain. London: Wiley.

Gouldner A.W. (1960). The norm of reciprocity: A preliminary statement, American Sociological Review, 25: 161-178. DOI: https://doi.org/10.2307/2092623

Hansmann, H. (1980). The role of non profit enterprise, Yale Law Journal, 89(2): 835-898. DOI: https://doi. org/10.2307/796089

Hassard, J., Teoh, K.R.H., Visockaite, G., Dewe, P. \& Cox, T. (2018). The cost of work-related stress to society: A systematic review, Journal of Occupational Health Psychology, 23(1): 1-17. DOI: https://doi.org/10.1037/ оср0000069

Helliwell, J.F. \& Huang, H. (2010). How's the job? Well-being and social capital in the workplace, Industrial and Labor Relations Review, 63(2): 205-227. DOI: https://doi.org/10.1177/001979391006300202

Hobfoll, S.E. (2001). The influence of culture, community, and the nested self in the stress process: Advancing conservation of resources theory, Applied psychology, 50(3): 337-421. DOI: https://doi.org/10.1111/1464-0597.00062

Hudson, M. (1999). Managing Without Profit. London: Penguin. 
ILO (2012). SOLVE: Integrating health promotion into workplace OSH policies-trainer's guide. Geneva: International Labour Organization.

ILO (2016). Workplace stress: A collective challenge. Geneva, Switzerland: International Labour Organization.

Inoue, M., Tsurugano, S. \& Yano, E. (2011). Job stress and mental health of permanent and fixed-term workers measured by effort-reward imbalance model, depressive complaints, and clinic utilization, Journal of Occupational Health, 53(2): 93-101. DOI: https://doi.org/10.1539/joh.L10098

Johnson, J.V. \& Hall, E.M. (1988). Job strain, work place social support, and cardiovascular disease: A cross-sectional study of a random sample of the Swedish working population, American Journal of Public Health, 78(10): 13361342. DOI: https://doi.org/10.2105/AJPH.78.10.1336

Kahn, R.L. (1980). Conflict, ambiguity, and overload: Three elements in job stress. In: D. Katz, R. Kahn, \& J. Adams (Eds.), The study of organizations. San Francisco, CA: Jossey-Bass, pp. 418-428.

Kahn, R.L., Wolfe, D.M., Quinn, R.P., Snoek, J.D. \& Rosenthal, R.A. (1964). Organizational stress: Studies in role conflict and ambiguity. New York, NY: Wiley.

Karasek, R.A. (1979). Job demands, job decision latitude, and mental strain: Implications for job redesign, Administrative Science Quarterly, 24(2): 285-308. DOI: https://doi.org/10.2307/2392498

Karasek, R. \& Theorell, T. (1990). Healthy work: Stress, productivity and the reconstruction of the working life. New York, NY: Basic Books.

Karkoulian, S., Srour, J. \& Sinan, T. (2016). A Gender Perspective on Work-Life Balance, Perceived Stress, and Locus of Control, Journal of Business Research, 69(11): 4918-4923. DOI: https://doi.org/10.1016/j.jbusres.2016.04.053

Leiter, M.P. \& Maslach, C. (1988). The impact of interpersonal environment on burnout and organizational commitment, Journal of Organizational Behavior, 9(4): 297-308. DOI: https://doi.org/10.1002/job.4030090402

Li, C., Wu, K.C. \& Johson, D.E. (2016). The impact of balance-focused attitudes on job stress: Gender differences evidenced in American and Chinese samples, International Journal of Psychology, 1: 1-9. DOI: https://doi. org/10.1002/ijop.12254

Lunau, T., Siegrist, J., Dragano, N. \& Wahrendorf, M. (2015). The association between education and work stress: Does the policy context matter? PLoS One, 10(3): e0121573. DOI: https://doi.org/10.1371/journal.pone.0121573

Makhija, P., Naidu, G. \& Rakesh, T.N. (2016). Occupational stress amongst women employees - a review of literature, Asiapacific Journal of research, 1(12): 249-57.

Mayo, M., Sanchez, J.I., Pastor, J.C. \& Rodriguez, A. (2012). Supervisor and co-worker support: A source congruence approach to buffering role conflict and physical stressors, The International Journal of Human Resource Management, 23: 3872-3889. DOI: https://doi.org/10.1080/09585192.2012.676930

McKenzie, K., Whitley, R. \& Weich, S. (2002). Social capital and mental health, British Journal of Psychiatry, 181(4): 280-283. DOI: https://doi.org/10.1192/bjp.181.4.280

Mittal, M. \& Bhakar, S.S. (2018). Examining the impact of role overload on job stress, job satisfaction and job performance: a study among married workingwomen in banking sector, International Journal of Management Study, 7(1): 2231-2528. DOI: https://doi.org/10.18843/ijms/v5i2(7)/01

Nappo, N. (2019). Is there an association between working conditions and health? An analysis of the Sixth European Working Conditions Survey data. PLoS One. DOI: https://doi.org/10.1371/journal.pone.0211294

Pomerantz, S.D. (1991). Predictive Indicators of Job Burnout in Nonprofit Organizations, Institute for Nonprofit Organization Management Working Paper n. 15. San Francisco: University of San Francisco.

Pugno, M. \& Depedri, S. (2010). Job performance and job satisfaction: An integrated survey, Economia Politica, 27(1): 175-210.

Ridder, H. G. \& McCandless, A. (2010). Influences on the architecture of human resource management in nonprofit organizations: An analytical framework, Nonprofit and Voluntary Sector Quarterly, 39: 124-141. DOI: https://doi. org/10.1177/0899764008328182 
Rose-Ackerman, S. (1996). Altruism, nonprofits, and economic theory, Journal of Economic Literature, XXXIV: 701-728.

Russell, H., Bertrand, M., Dorothy, W. \& Éamonn, F. (2018). Job stress and working conditions: Ireland in comparative perspective-an analysis of the European working conditions survey, Research series, economic and social research institute (ESRI), n. RS84. Dublin, Ireland: ESRI. DOI: https://doi.org/10.26504/rs84

Sager, J.K. (1994). A structural model depicting salespeople’s job stress, Journal of the Academy of Marketing Science, 22(1): 74-84. DOI: https://doi.org/10.1177/0092070394221007

Siegrist, J. \& i Rödel, A. (2006). Work stress and health risk behaviour, Scandinavian Journal of Work Environment \& Health, 32 (6), 473-481. DOI: https://doi.org/10.5271/sjweh.1052

Somaratne, C.S.N., Jayawardena, L.N.A.C. \& Perera, B.K. (2017). Impact of adversity quotient on stress levels of middle-level managers of non-governmental organisation (NGO) sector, Tropical Agricultural Research, 29(1): 45-54. DOI: https://doi.org/10.4038/tar.v29i1.8296

Sousa-Poza, A. \& Sousa-Poza, A.A. (2000). Well-being at work: a cross national analysis of the levels and determinants of job satisfaction, Journal of Socio-Economics, 29: 517-38. DOI: https://doi.org/10.1016/S1053-5357(00)00085-8

Tan, K. \& Tay, L. (2018). Relationships and well-being. In R. Biswas-Diener \& E. Diener (Eds), Noba textbook series: Psychology. Champaign, IL: DEF publishers.

Thoits, P. A. (2010). Stress and health: Major findings and policy implications, Journal of Health and Social Behavior, 51 (Special Issue): S41-S53. DOI: https://doi.org/10.1177/0022146510383499

Um, B., Joo, H. \& Her, D. (2018). The relationship between elementary school teachers' work motivation and wellbeing: The mediating effects of principal leadership and work stress, International Journal of Social Science Studies, 6(12), 67-78. DOI: https://doi.org/10.11114/ijsss.v6i12.3762

Vercamer, S. (2018). Stress at work. Report to committee on social affairs, health and sustainable development. Council of Europe. Available at: http://website-pace.net/documents/19855/4491159/20181204-WorkStress-EN. pdf/6c87997b-366a-4a92-8e80-b540d4cc06d8 [Accessed: February, 2020]

Wehmeier, S. (1998). Oxford word power dictionary. Oxford: Oxford University Press. 